\title{
Fundamentals of the energy model of reinforced concrete elements and structures deformation
}

\author{
O. V. Romashko-Maistruk \\ National University of Water Management and Nature Recourses Use, Rivne, Ukraine \\ Corresponding author. E-mail: romashkoolena@gmail.com
}

Paper received 23.08.20; Accepted for publication 16.09.20.

\begin{abstract}
https://doi.org/10.31174/SEND-NT2020-238VIII29-02
\end{abstract}
\begin{abstract}
This article presents a critical analysis of existing models of reinforced concrete elements and structures deformation. The most important requirements to the model which could claim a generalized role are formed. The most important provisions of such a model have been developed. It is based on the deformation-force model of reinforced concrete resistance to force and the hypothesis of invariance in units of volume and potential energy independence of reinforced concrete element deformation from the loading mode. At the same time, this hypothesis is presented as an energy criterion for depletion of reinforced concrete elements bearing strength, which allows to calculate the total and residual resources of these elements during their long operation.
\end{abstract}

Keywords: reinforced concrete elements, deformation model, state diagram, curvature, energy resource.

Introduction. Reproduction of the reinforced concrete elements and structures real stress-strain state at any stage of their deformation has always been one of the main tasks of the reinforced concrete theory. Its implementation was largely associated with the development or creation of a general model of reinforced concrete elements deformation. Such a model should be universal and:

- be based on general assumptions, hypotheses and assumptions of the deformed solid mechanics;

- have clear criteria for the onset of reinforced concrete elements and structures limiting states in real conditions of their operation;

- contribute to the disclosure of internal static uncertainty of the reinforced concrete elements cross-section;

- to ensure the methodological consistency of all calculations of reinforced concrete elements and structures for limiting states;

- implemented using both software (numerical) and non-software (engineering) calculation methods;

- provide maximum or complete deprivation of the various empirical dependencies, parameters and coefficients influence;

- allow to establish not only the actual technical condition, but also the residual life of reinforced concrete elements and structures during their long-term operation.

Analysis of recent research and publications. The implementation of most of the above requirements in the so-called "force" models $[1,2]$ was absolutely impossible due to the use of concrete stresses idealized rectangular diagram in both the compressed and stretched zones of the element section.

"Deformation" models [3-6], due to the use of concrete deformation complete diagrams $\sigma_{c}-\varepsilon_{c}$, in general, allow to ensure the methodological unity of reinforced concrete elements and structures calculations for limiting states, since they are mainly based on general hypotheses of deformable solid mechanics. However, when integrating diagrams $\sigma_{c}-\varepsilon_{c}[3,4]$, as well as when using their simplified forms $[5,6]$, the internal static uncertainty of reinforced concrete elements cross-section has to be disclosed through numerous iterations using software methods and complexes involving a number of empirical parameters and coefficients.
The closest to the reinforced concrete elements generalized deformation model today is the deformation-force model [7]. It substantiates why it is impossible to construct a generalized model of reinforced concrete elements deformation with the help of diagrams $\sigma_{c}-\varepsilon_{c}$ alone, even complete ones [8]. The defining element of the deformation-force model is not the concrete deformation diagram $\sigma_{c}-\varepsilon_{c}$, but the state diagram of the reinforced concrete element $M-1 / r$, which characterizes its rigidity. This is its main difference from deformation models. However, this model also requires further development, especially in assessing the actual technical state of reinforced concrete elements and structures and calculating their residual resource.

The purpose and objectives of the research. Therefore, these studies are aimed at further improving the deformation-force model of reinforced concrete elements and structures resistance to force effects in terms of calculating their total and residual (after long-term operation) resources.

Research results. It is known that in the deformationforce model, the main deformation and force parameters of an element state are interconnected by a stiffness function $D=M /(1 / r)$. At the same time, these parameters can be combined with each other using another characteristic - the potential energy spent on deformation of a reinforced concrete element in its unit volume $W=M \cdot(1 / r)$ [9]. Then the methodology for calculating the total resource of reinforced concrete elements can be built using the same parameters of field studies (surveys), which directly or indirectly characterize their rigidity.

The reinforced concrete elements residual life is usually calculated by deterministic or variational methods [10, 11] on the basis of the totality of materials defects, damages and established strength characteristics visually revealed during field examinations. In this case, the deformation parameters of the elements themselves are generally not taken into account.

However, it is precisely the deflection $f$ and the spacing $s_{r}$ and the crack opening width $w_{k}$, the values of which can be measured directly during inspection by any instrumental (geodetic, photogrammetric, stereophoto- 
grammetric, etc.) methods, that make it possible to determine one of the main deformation parameters of a reinforced concrete element or structure - their curvature. In particular, by the magnitude of the measured deflection, one can fairly easily determine the averaging curvature of a bending element at any stage of its deformation

$$
1 / r=f /\left(s \cdot l^{2}\right)
$$

where $s$ is the coefficient depending on the loading and fixing schemes of the element; $l$-calculated length of a reinforced concrete element.

In general, the actual resource of a bending reinforced concrete element under short-term exposure to full load or the potential deformation energy spent on its destruction (Fig. 1) can be calculated by the following expression

$$
\begin{aligned}
& W_{u f}=\int_{o}^{1 / r_{u f}} M d(1 / r)=\int_{o}^{1 / r_{u f}}\left[\left(D_{o} \cdot(1 / r)-\frac{M_{u f}}{\left(1 / r_{u f}\right)^{2}} \cdot(1 / r)^{2}\right) /\left(1+(K-2) \frac{(1 / r)}{\left(1 / r_{u f}\right)}\right)\right] d(1 / r)= \\
& =\frac{M_{u f} \cdot\left(1 / r_{u f}\right)}{(K-2)}\left[-\frac{1}{2}+\frac{(K-1)^{2}}{(K-2)}-\left(\frac{K-1}{K-2}\right)^{2} \ln (K-1)\right],
\end{aligned}
$$

where the deformation $1 / r$ and force $M$ parameters of the element state are interconnected by the its state diagram [12]

$$
M=\frac{D_{o} \cdot 1 / r-M_{u f} \cdot\left((1 / r) /\left(1 / r_{u f}\right)\right)^{2}}{1+\left(D_{o} / M_{u f}-2 /\left(1 / r_{u f}\right)\right) \cdot(1 / r)} ;
$$

with the value of the total initial stiffness of the reinforced concrete element $D_{o}$ and the characteristic of its ultimate deformability $K=D_{o} \cdot(1 / r)_{u f} / M_{u f}$.

- static $M=f\left(\varepsilon_{c}, \varepsilon_{c t}, \varepsilon_{s}\right), \quad N=f\left(\varepsilon_{c}, \varepsilon_{c t}, \varepsilon_{s}\right)$;

- geometric $1 / r=f\left(\varepsilon_{c}, \varepsilon_{c t}, \varepsilon_{s}\right)$;

- physical $\sigma_{c}=f\left(\varepsilon_{c}\right), \sigma_{c t}=f\left(\varepsilon_{c t}\right), \sigma_{s}=f\left(\varepsilon_{s}\right)$

relations with the addition of its [12] analytical dependence of the element state diagram " $M-(1 / r)$ " (3) and the function of compressed concrete limiting deformations $\varepsilon_{c u}$, obtained using the extreme Fermat criterion to the state diagram (3) $d M / d(1 / r)=0$.

However, when designing reinforced concrete elements and structures, one should speak not about the actual, but about the calculated limit state. It can occur long before the physical destruction of reinforced concrete elements due to excessive development of deflections $f_{u}$ or excessive width of normal crack opening $w_{u}$ (Fig. 1), which is typical for the case of reinforcement yield. Under such circumstances, the calculated value of the averaged curvature of the bending element at the deformation limiting stage according to formula (1) will be

$1 / r_{u}=f_{u} /\left(s \cdot l^{2}\right)$

with a design bearing strength $M_{u}$ according to (3)

$$
M_{u}=\frac{D_{o} \cdot 1 / r_{u}-M_{u f} \cdot\left(\left(1 / r_{u}\right) /\left(1 / r_{u f}\right)\right)^{2}}{1+\left(D_{o} / M_{u f}-2 /\left(1 / r_{u f}\right)\right) \cdot\left(1 / r_{u}\right)} \text {. }
$$

It is recommended to calculate the defining forcen $M_{u f}$ and deformation $1 / r_{u f}$ parameters of the actual limiting state of elements using the deformation-force model of reinforced concrete elements and structures resistance to force effects and the main provisions of a deformable solid mechanics according to the following system of generally accepted

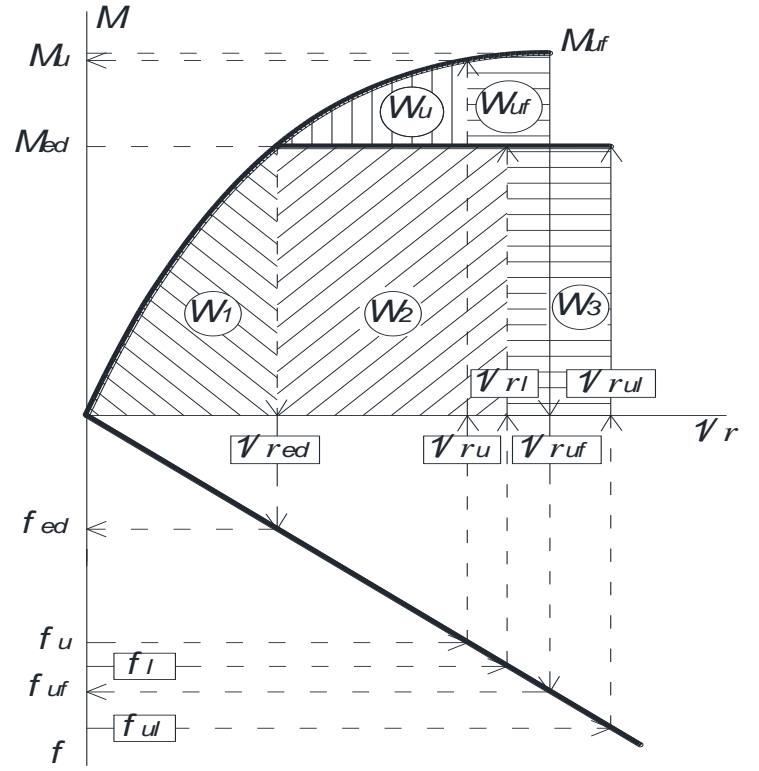

Figure 1. To the calculation of the total and residual life of reinforced concrete elements and structures: $M_{e d}, f_{e d}$, $1 / r_{e d}$ - bending moment, deflection and curvature of the element under short-term action of the operational load; $M_{u}$, $f_{u}, 1 / r_{u}$ - calculated values of the bending moment, deflection and curvature of an element at the limiting stage of its deformation under a full load short-term action; $M_{u f}, f_{u f}$, $1 / r_{u f}$ - the actual values of the bending moment, deflection and curvature of the element at the limiting stage of its defor- 
mation under a full load short-term action; $f_{l}, 1 / r_{l}-$ the calculated values of the deflection and curvature of the element at the time of its examination under prolonged exposure to the operational load; $f_{u l}, 1 / r_{u l}$ - the calculated values of the deflection and curvature of the element at the limiting stage of its deformation under prolonged exposure to the operational load; $W_{u f}, W_{u}$ - the actual and calculated value of the potential energy of the element deformation at the limiting stage; $W_{1}$ - potential energy of the element deformation under short-term

$$
\begin{aligned}
& W_{u}=\int_{o}^{1 / r_{u}} M d(1 / r)=\int_{o}^{1 / r_{u}}\left[\left(D_{o} \cdot(1 / r)-\frac{M_{u f}}{\left(1 / r_{u f}\right)^{2}} \cdot(1 / r)^{2}\right) /\left(1+(K-2) \frac{(1 / r)}{\left(1 / r_{u f}\right)}\right)\right] d(1 / r)= \\
& =\frac{M_{u f}}{(K-2)}\left[-\frac{\left(1 / r_{u}\right)^{2}}{2 \cdot\left(1 / r_{u f}\right)}+\frac{\left(1 / r_{u}\right) \cdot(K-1)^{2}}{(K-2)}-\left(1 / r_{u f}\right) \cdot\left(\frac{K-1}{K-2}\right)^{2} \ln \left(1+(K-2) \frac{1 / r_{u}}{1 / r_{u f}}\right)\right] .
\end{aligned}
$$

When predicting the residual energy resource according to the generalized state diagram (3), the averaging action of the operational load; $W_{2}, W_{3}$ - the calculated value of the potential energy of the element deformation at the time of its examination and at the limiting stage with prolonged exposure to the operating load

Then the calculated resource of the bending reinforced concrete element under short-term exposure to full load (Fig. 1) should be calculated according to (2) by the following expression

$$
\frac{1}{r_{e d}}=\frac{1 / r_{u f}}{2 M_{u f}}\left[\left(1-\frac{M_{e d}}{M_{u f}}\right) \frac{D_{o}}{r_{u f}}+2 M_{e d}-\sqrt{\left(\left(1-\frac{M_{e d}}{M_{u f}}\right) \frac{D_{o}}{r_{u f}}+2 M_{e d}\right)^{2}-4 M_{e d} \cdot M_{u f}}\right]
$$

and the corresponding potential deformation energy

$$
\begin{aligned}
& W_{1}=\int_{o}^{1 / r_{e d}} M d(1 / r)=\int_{o}^{1 / r_{e d}}\left[\left(D_{o} \cdot(1 / r)-\frac{M_{u f}}{\left(1 / r_{u f}\right)^{2}} \cdot(1 / r)^{2}\right) /\left(1+(K-2) \frac{(1 / r)}{\left(1 / r_{u f}\right)}\right)\right] d(1 / r)= \\
& =\frac{M_{u f}}{(K-2)}\left[-\frac{\left(1 / r_{e d}\right)^{2}}{2 \cdot\left(1 / r_{u f}\right)}+\frac{\left(1 / r_{e d}\right) \cdot(K-1)^{2}}{(K-2)}-\left(1 / r_{u f}\right) \cdot\left(\frac{K-1}{K-2}\right)^{2} \ln \left(1+(K-2) \frac{1 / r_{e d}}{1 / r_{u f}}\right)\right] .
\end{aligned}
$$

The increase in the potential energy of the reinforced concrete element deformation due to the long-term action of the operating load (Fig. 1) at the time of the survey will be

$$
\begin{aligned}
& W_{3}=W_{u}-W_{1}-W_{2}=\frac{M_{u f} \cdot\left(1 / r_{u f}\right)}{(K-2)}\left[-\frac{1}{2}+\frac{(K-1)^{2}}{(K-2)}-\left(\frac{K-1}{K-2}\right)^{2} \ln (K-1)\right]- \\
& -\frac{M_{u f}}{(K-2)}\left[-\frac{\left(1 / r_{e d}\right)^{2}}{2 \cdot\left(1 / r_{u f}\right)}+\frac{\left(1 / r_{e d}\right) \cdot(K-1)^{2}}{(K-2)}-\left(1 / r_{u f}\right) \cdot\left(\frac{K-1}{K-2}\right)^{2} \ln \left(1+(K-2) \frac{1 / r_{e d}}{1 / r_{u f}}\right)\right]- \\
& -M_{e d} \cdot\left(1 / r_{l}-1 / r_{e d}\right) .
\end{aligned}
$$

The averaged curvature limiting value of a bending reinforced concrete element $1 / r_{u l}$ under prolonged exposure to a service load can be predicted by the expression $1 / r_{u l}=W_{3} / M_{e d}+1 / r_{l}$.

In a similar way, the parameters of the total and residual energy resource of reinforced concrete elements and structures are calculated according to other characteristics, namely, by the spacing $s_{r}$ and the opening width $w_{k}$ of normal cracks. According to the flat sections hypothesis, it is recommended to connect them through the materials deformations with the averaged curvature of a reinforced concrete element in the design section by the following dependence

$$
1 / r=\left(\varepsilon_{c l}+w_{k} / s_{r}+\varepsilon_{c t m}\right) / d
$$

where $d$ is the element working cross-sectional height.
$W_{2}=M_{e d} \cdot\left(1 / r_{l}-1 / r_{e d}\right)$.

Then the calculated value of the residual energy resource of a reinforced concrete element, taking into account expressions (7) - (10), will be (Fig. 1)
Thus current values of concrete relative deformations of the most compressed face at loadings long action is expedient to predict on expression

$$
\varepsilon_{c l}=\varepsilon_{c} \cdot\left(1+\varphi\left(t, t_{0}\right)\right),
$$

where $\varepsilon_{c}$ are the concrete relative deformations of the most compressed face under short-term loads action; $\varphi\left(t, t_{0}\right)$ - the value of the compressed concrete creep coefficient for the external load action, duration $\left(t-t_{0}\right)$.

Ultimate deformations of tensile concrete can be taken according to [13] equal $\varepsilon_{c t m}=2 \cdot E_{c} / f_{c t k}\left(E_{c}\right.$ - modulus of concrete elasticity; $f_{c t k}$ - characteristic value of concrete tensile strength).

Conclusions. Thus, the proposed energy model of the reinforced concrete elements and structures deformation is based on one of the main hypotheses - invariability per unit volume and independence from the loading mode of the potential energy of a reinforced concrete element 
deformation spent on its destruction. At the same time, this hypothesis can be considered as an energy criterion not only for the general, but also for the residual life of reinforced concrete elements and structures after their long-term operation and can be used in the appropriate calculation methods development.

\section{REFERENCES}

1. Проектирование железобетонных конструкций: справоч. пособие / Голышев А. Б. и др.; под ред. А. Б. Голышева. Київ: Будівельник, 1985. 496 с.

[Design of reinforced concrete structures: reference book. manual / Golishev A. B., et al .; ed. A. B. Golysheva. Kiev: Budivelnik, 1985. 496 p. (in Russian)].

2. Залесов А. С., Кодыш Э. Н., Лемыш, Л. Л. и др. Расчет железобетонных конструкций по прочности, трещиностойкости и деформациям. Москва: Стройиздат, 1988. $320 \mathrm{c}$.

[Zalesov A. S., Kodysh E. N., Lemysh L. L. et al. Calculation of reinforced concrete structures for strength, crack resistance and deformations. Moscow: Stroyizdat, 1988. 320 p. (in Russian)].

3. Attard M. M., Setunge S. Stress-strain relationship of confined and unconfined concrete. ACI Materials Journal. 1996. V. 93, No. 5. P. 432-442.

4. Бамбура А. М. Експериментальні основи прикладної деформаційної теорії залізобетону: дис. ... докт. техн. наук: 05.23.01 / НДІБК. Київ, 2005. 379 с.

[Bambura A. M. Experimental bases of the applied deformation theory of reinforced concrete: dis. ... Dr. tech. Sciences: 05.23.01 / NDIBK. Kyiv, 2005. 379 p. (in Ukrainian)].

5.EN 1992-1-1. Eurocode 2: Design of Concrete Structures. Part 1-1: General Rules and Rules for Buildings. [Final Draft, December, 2004]. Brussels: CEN. 2004. 225 p.

6. Дорофеев В. С., Барданов В. Ю. Расчет изгибаемых элементов с учетом полной диаграммы деформирования бетона: монография. Одесса: ОГАСА, 2003. 210 с.

[Dorofeev V. S., Bardanov V. Yu. Calculation of bending elements taking into account the complete diagram of concrete deformation: monograph. Odessa: OGASA, 2003. 210 p. (in Russian)]

7. Romashko V., Romashko O. The construction features of the deformation and force model of concrete and reinforced concrete resistance. MATEC Web of Conf. 2017. Vol. 116. 02028.

https://doi.org/10.1051/matecconf/201711602028

8. Ромашко В. М. Деякі особливості діаграми деформування бетону. Ресурсоекономні матеріали, конструкиії, будівлі та споруди: зб. наук. пращь. 2006. Вип.14. С. 294-301.
[Romashko V. M. Some features of the concrete deformation diagram. Resource-saving materials, structures, buildings and structures: collection of articles. sciences. works. 2006. Vip. 14. P. 294-301. (in Ukrainian)].

9. Romashko V. M. and Romashko O. V. Energy resource of reinforced concrete elements and structures for the deformation-force model of their deformation. IOP Conf. Ser.: Mater. Sci. Eng. 2019. Vol. 708, No. 1. 012068. https://doi.org/10.1088/1757-899X/708/1/012068

10. Шматков С. Б. Расчёт остаточного ресурса строительных конструкций зданий и сооружений. Вестник ЮУрГУ: Строительство и архитектура. 2007. Вып. 5, № 22. С. 56-57.

[Shmatkov S. B. Calculation of the residual resource of building structures of buildings and structures. SUSU Bulletin: Building and Architecture. 2007. Issue 5, No. 22. P. 5657. (in Russian)].

11. Сущев С. П. Самолинов Н. А., Адаменко И. А. Остаточный ресурс конструкций (сооружений) и возможные методы его оценки. Предотвращение аварий зданий и сооружений: сб. науч. трудов. 2009. Вып. 8. С. 320-327.

[Sushchev S. P. Samolinov N. A., Adamenko I. A. Residual resource of structures (structures) and possible methods of its assessment. Prevention of accidents in buildings and structures: collection of articles. scientific. works. 2009. Issue 8 . P. 320-327. (in Russian)].

12. Ромашко В. М. Деформаційно-силова модель опору бетону і залізобетону: монографія. Рівне: О. Зень, 2016. $424 \mathrm{c}$.

[Romashko V. M. Deformation-force model of concrete and reinforced concrete resistance: monograph. Rivne: O. Zen, 2016. 424 p. (in Ukrainian)].

13. ДСТУ Б В.2.6-156: 2010. Конструкції будинків і споруд. Бетонні та залізобетонні конструкції з важкого бетону. Правила проектування. Київ: Мінрегіонбуд України, 2011. $123 \mathrm{c}$.

[DSTU B B.2.6-156: 2010. Constructions of buildings and structures. Concrete and reinforced concrete structures made of heavy concrete. Design rules. Kyiv: Ministry of Regional Development of Ukraine, 2011. 123 p. (in Ukrainian)]. 